\title{
Studying Foreign Experience of Physical Culture and Sport Sphere Financing
}

\author{
Vishnevskaya N.G. \\ Tax Policy and Customs-Tariff Regulation Department \\ Finance University under the Government of the Russian \\ Federation \\ Moscow, Russia \\ ngvishnevskaya@fa.ru
}

\author{
Vishnevskiy D.A. \\ Laboratory of studying organizational-economic problems \\ in the sphere of physical culture and sport \\ Federal Scientific Center of Physical Culture and Sport \\ Moscow, Russia \\ dvishnevskiy@yandex.ru
}

Steshenko J.A.

Laboratory of studying organizational-economic problems in the sphere of physical culture and sport Federal Scientific Center of Physical Culture and Sport

Moscow, Russia

julia11st@vniifk.ru

\begin{abstract}
The article presents analysis of financing physical culture and sport sphere in the Russian Federation. It considers different mechanisms of sports sphere private financing in some foreign countries: homesteads expenditure and volunteership, subvention of public sector at a national, regional and local levels, national lotteries, income from mass media received by sports events organizers, sponsorship and patronship, gambling, endowment-fund and others. The authors studied scientific works of native and foreign scientists in the sphere of sport financing. On the basis of analyzing foreign experience authors offered the directions of financing mechanisms improvement in the sphere of physical culture and sport in the Russian Federation. The authors underline the necessity to reconsider the mechanism of financing physical culture and sport in terms of widening the tools of tax stimulation.
\end{abstract}

Keywords-financing; physical culture and sport; tax stimulation; tax benefits; sport; state budget.

\section{INTRODUCTION}

The questions of physical culture and sport development nowadays take an important place in state policy of the Russian Federation and are considered at a high level. According to article 38 of the Federal law of December, 4, 2007 №329-FZ "On physical culture and sport in the Russian Federation", physical culture and sport financing is the commitment of the state. Municipal establishments, according to the law, have to provide conditions for mass sport and physical culture development. Subjects of the Russian Federation finance organization and regional sports events and have to provide material-technical support of regional sports national teams. The commitment of the Russian Federation is to provide material-technical support of sports national teams, physical culture, sport and healthy life style popularization and others. It was also stated that physical culture and sport financing can be realized owing to other not forbidden by law sources: income from sponsorship and lotteries organization, own income of sports organizations, financial resources of population attraction and etc. Official statistics doesn't give information about the amount of inflow from this kind of funding source, but we can affirm that the base of the Russian sport development nowadays is state financing. According to table 1 within the considered period since 2013 till 2018 the expenditure of the Russian Federation subjects consolidated budgets spent on physical culture and sport were higher than the expenditure of the federal budget. In 2018 the amount of the federal budget expenditure was 64,02 milliard rubles and consolidated budgets of the subjects - 282,84 milliard rubles.

TABLE 1. DYNAMICS OF EXPENDITURE FOR PHYSICAL CULTURE AND SPORT IN

\begin{tabular}{|c|c|c|c|c|c|c|}
\hline \multicolumn{1}{|c|}{ RUSSIA DURING THE PERIOD 2013-2018 } \\
\hline Year & $\mathbf{2 0 1 3}$ & $\mathbf{2 0 1 4}$ & $\mathbf{2 0 1 5}$ & $\mathbf{2 0 1 6}$ & $\mathbf{2 0 1 7}$ & $\mathbf{2 0 1 8}$ \\
\hline $\begin{array}{c}\text { Expenditure of } \\
\text { the federal } \\
\text { budget, milliard } \\
\text { rubles }\end{array}$ & 68,00 & 71,16 & 72,96 & 59,55 & 96,14 & 64,02 \\
\hline $\begin{array}{c}\text { Expenditure of } \\
\text { consolidated } \\
\text { budgets of the } \\
\text { subjects of the } \\
\text { Russian } \\
\text { Federation , } \\
\text { milliard rubles }\end{array}$ & 170,82 & 191,11 & 193,11 & 211,75 & 253,73 & 282,84 \\
\hline Source: https://www.minfin.ru/ru/statistics/ & & & & & \\
\hline
\end{tabular}

In the Russian Federation in order to increase the competitiveness of the Russian sport on the International World arena and also in order to create the conditions, which would provide the opportunity to go in for systematic physical culture and sport, several state programs exist. The volume of financing the Federal target program "Physical culture and sport development in the Russian Federation within the period $2016-2020$ " is 77,59 milliard rubles, including owing to 
L.A., Minasyan D.S., Kazakova O.A., Makhova E.V. and others.

Thus, we can state that the mechanism of physical culture and sport financing was described in many scientific works of native and foreign scientists. Nevertheless, the questions of foreign experience use in financing sport in the Russian practice are still urgent.

\section{RESEARCH METHODOLOGY}

There are two models of sports sphere financing in the world. The first model is European. It is characterized by mixed financing with high specific weight of state budget resources. The second model is American. It is characterized by indirect support of state, based on tax stimulation of sports activity. Further we will consider foreign experience of physical culture and sport sphere financing.

According to the research concerning mass sport financing in European Union [11], there are 5 key streams, which provide mass sport financing. Let's consider the forms of sport financing in European Union in details.

1. Homesteads expenditure and volunteership. One of the greatest investments into mass sport are the athletes themselves. They pay membership fees in order to take part in sports events and also their expenditure for sports equipment. Membership fees are the main source of income for mass sport and are given to pay for the buildings and equipment. At the same time, sports clubs realize national control and professional sport financing through the mechanism of membership fees. Volunteers are also important for mass sport.

2. Subvention of public sector at a national, regional and local levels. Sport is financed in the states-members of EU both centrally and through local authorities, in a form of direct financing and indirect state support, for example, through tax benefits. The volume and degree of local authorities participation in EU countries is different. The states-members of EU can place demands for state support use by sports sector, in order to provide correct state resources spending.

3. Sponsorship, patronship and donations. Most big sponsor affairs are connected with the separate clubs at an elite level. However, regardless of the fact that sponsorship in mass sport can give lower sums, they are very often more significant for a local club or establishment. Depending on methodology there are different volumes of sponsorship in EU, however, the value of sponsorship for mass sport is always significant. For example, in Germany it is calculated that recreational kinds of sport get sponsorship twice more than professional kinds of sport and mass sport gets 2,1 milliard euro a year, professional sport - 1,1 milliard euro.

4. Income from state lotteries, fees from bets and gambling operators. Lotteries and fees from bets and gambling operators are used by states-members in order to finance sport. According to the research works 2,1 milliard euro is invested into mass sport by Government through lotteries and fees in lotteries. Only 0,11 milliard euro is invested directly into sport through set by law fees. There are differences in the national 
schemes of income regulation from lotteries between the countries of EU concerning the contribution of these services into sport financing. The operators of the National lottery pay fees, taxes or dues into state budget in order to provide general interests of the activity financing. State considers how to spend this income, sometimes with some assignations, given specially for sport (mainly for sports federations and associations). One more way of sport financing is online gambling. This segment becomes more and more popular every year. Bets in sport are the form of sports competitions commercial use. In France people can legally make bets online through the private operator, which should be registered in France and have a contract with the independent responsible authority of online gambling. Apart from financial resources, which are directed toward private operators in order to pay for the right for sports events, for sports event organizer, according to all dues $1,8 \%$ fee is taken into National center of sport development for mass sport needs.

5. Income from mass media paid for sports events organizers. The right of mass media use for the direct mass sport financing is the mechanism of vertical solidarity realization. The rights of mass media are the most financially beneficial active of sports organizations.

Let's discuss sport and physical culture financing in details by the example of the United Kingdom. The United Kingdom realizes modern approach to physical culture and sport regulation. The aim of this approach is in indirect state influence on sport. Department for Digital, Culture, Media \& Sport is in charge of the politics in the sphere of sport and physical culture in the United Kingdom. The main objectives of the Department in the sphere of sport are the following: sport availability increase, including female sport and also Great Britain sports interests promotion on the International arena. The Department mentions that 1 milliard pound sterling is invested into art, museums, mass media and sport together with social benefits gives one fourth of trillion to economics in general. The Department delegates authority to distribute budget resources and realize state policy in the sphere of sport to several agencies.

«UK Sport» is a national sports agency, which is financed by the government and a National lottery. The mission of the agency is in partner work for success achievement of world class, Olympic and Paralympic sport in Great Britain. Investing and strategic direction of «UK Sport» helped British athletes win 65 Olympic and 120 Paralympic medals in London in 2012 and 4 Olympic and 6 Paralympic medals in Sochi in 2014. During 2017-2018 «UK Sport» agency got general income 139,9 million pound sterling, including grant from Department for Digital, Culture, Media \& Sport 62 million pound sterling, money from the National lottery fund 74,9 million pound sterling. General sum of spent money was 157,7 million pound sterling, 120,8 million pound sterling of which were directed toward world level programs [12].

«Sport England» agency specializes in mass sport development in England. In "On the way to an active nation" strategy it is stated how the work with the national and local partners happens in order to let everybody take advantage of physical activity. The agency has the ways of financing sports activity such as social active fund, investing fund, small grants and etc.. "On the way to an active nation" strategy makes the agency invest 2 million pounds into organizations, which are able to attract less physically active people. The agency invests both into big projects and buildings and infrastructure support. In 2017-2018 the income of «Sport England» agency was 304,6 million pound sterling, 33\% of which $(101,3$ million pound sterling) were given by Department for Digital, Culture, Media \& Sport, 67\% (203,3 million pound sterling) were given by National lottery [13].

Great Britain is the country, which has European model of sport financing, great specific weight in agencies income, which influence directly on sport development, form the income from the National lottery. Great Britain government doesn't have direct influence on sport and physical culture regulation, but using sports agencies it achieves set aims of the policy.

The structure of sports system in Germany is based on state structure of the country, which consists of 16 federal lands (subjects of federation) and a great number of communities. Sports system is divided into a national level, the level of lands and local level. 16 state sports confederations present the interest of the local sports confederations and almost 90 thousand voluntary sports clubs. In Germany policy in the sphere of sport is based on three main principles: autonomy of sport, subsidiarity of sport financing and cooperation between state establishments and sports organizations [14]. Autonomy means that sport doesn't depend on state and has independent responsibility. Following the principle of subsidiarity sports organizations should first deplete own financial resources, before it demands state support. Thus, state financing is an additional source.

Different levels of authority finance different aspects of sport. National government finances sports events, which present national interest, including Germany representation by the athletes at international competitions. At a state level competitive sport and the athletes, which belong to the corresponding teams of the state level are supported [15]. While state and social organizations are responsible for amateur and entertaining sport support [16], most part of mass sport and voluntary sports clubs financing comes from local communities. Sport support and financing are written in the constitution of all lands, apart from Hamburg [15]. In half of German subjects of federation special laws are set concerning sport. At the same time, other part of Germany is based on theses of National policy in terms of sports financing. At a social level sport financing is regulated in accordance with the local sports policy, municipal authorities can independently decide how to support and finance voluntary sports clubs. Voluntary sports clubs get state financing, if they are uncommercial organizations, registered in accordance with the laws of Germany and have membership in sports confederation (at the level of the subject of federation or at a local level), or in association. In order to get subsidy from a state budget voluntary sports clubs should proceed with an application, which will have the aim of financing and the volume of own financial resources. Voluntary sports clubs get money for the following needs: sports environment, paying for 
competitions trips and training camps, for competitions and sports events organization.

Sport financing in Germany can be differentiated as the main financing and the definite kinds of activity, projects, sports buildings financing. The main financing is given to clubs in a form of the fixed rate calculated on the basis of the number of athletes and licensed coaches and calculation in terms of their increase. This principle of financing exists in other countries, for example, in Denmark the volume of subsidy depends on the number of athletes, who are younger than 25 years-old [17]. In Germany almost one in three citizens is the member of some club. Among children and teen-agers at the age of 7 - 14 years-old more than $80 \%$ of boys and more than $60 \%$ of girls are the members of some clubs. Policy in the sphere of sport in many countries, including Germany, includes state support during sports objects building and repair. Public sports buildings running is one of the main aims of the local authorities.

In Germany apart from direct state support indirect methods of support are widely used. Tax legislation in Germany provides tax benefits according to corporate tax for sports organizations, in case if the volume of income doesn't exceed the set sum, absolution from property taxation in terms of sports infrastructure objects.

American system of sport financing differs from European one. The main difference is in the form of state support. There is no direct financing and indirect methods use, first of all, absolution from taxation. In the USA there is almost no direct state interference into sport, but nevertheless, American athletes achieve high results every year. According to the research held by PricewaterhouseCoopers company in 2018 $[18,19]$, the main sources of sport sphere financing are the following: sponsorship, merchandising, rights for sports events broadcast in mass media and selling tickets for competitions. According to analytical forecast of PWC, sports market in the North America will grow in 3\% each year. In 2017 the volume was 69,1 milliard dollars, by 2022 it will be more than 80 milliard dollars. The right for sports events broadcast in mass media give the greatest part of income, specific weight of this source of financing in 2017 was 27,6\%, and according to analysists, by 2022 it will be more than 23 milliard dollars a year. Selling tickets for competitions is the second source of income, specific weight of which in 2017 was $27,5 \%$ and by 2022 it will be 21,2 milliard dollars. Sponsorship in 2017 gave sports sphere 16,7 2 milliard dollars and merchandising gave 14,4 milliard dollars. One more prospective source of sports sphere financing in the USA is sports betting, which till 2018 was illegal. After the Supreme court abolished betting prohibition in May 2018, the USA were able to decide independently the question of this kind of activity legalization. New Jersey, Nevada, Mississippi and other states legalized sports betting. According to analytical forecast of PWC only National football league can get 2,3 milliard dollars from sports betting, from which 1.7 milliard dollars would d form income from fans, 0,6 milliard dollars sponsorship, advertisement, commission income.

State support of sport in the USA in a form of financing stadiums building is realized through tax free municipal stock.
Since 2000 for the biggest American sports leagues: Major League baseball (MLB), National football League (NFL), National basketball association (NBA) and National hockey League (NHL), 45 stadiums were built and repaired, 36 of which were financed, at least partially, by state budget in a form of tax free municipal stock. General sum of tax free stock, released for these stadiums creation was about 13,0 milliard dollars. One more way of sport financing in the USA is endowment-fund use, which supports athletes in a form of education, health insurance and financial reward.

Among tax instruments, used in the USA in the sphere of sport, great importance have tax benefits according to property and land taxes, benefits according to income tax. Noncommercial organizations in the sphere of sport don't pay taxes, irrespective of the volume of income.

Sports industry development in China is directly connected with the level of economic development. Till the middle of 1990-s sport financing in China was realized by the state and government was responsible for different competitions organization, athletes training and support and etc.. The situation started to change in 1994, when China government, feeling lack of financial resources, used external investments. Professional China sport nowadays is ideologically supported by the state, which plans, organizes, regulates, controls and finances its development. Central sport management (former State sports committee) is a state authority, which defines the direction of development for all Chinese sport (mass, professional sport, school sport, sports and research Institutes, sports schools and associations) and at the same time, is influenced by the policy of Chinese Communist party. In China there are also such sources of sport financing, as the rights selling for sports events broadcast in mass media, sponsorship and national lotteries. Tax stimulation of physical culture and sport sphere in China is realized also at the level of special economic zones, the residents of which have considerable tax preferences.

\section{RESUlTS}

Considered above sources of physical culture and sport financing, which are used abroad, are different and can be adapted and successfully used in Russia. In Russia, as well as in European countries, state lotteries are organized in order to support physical culture and sport development. The lottery organizer is the Ministry of sport of the Russian Federation and the income from the lottery is $10 \%$ from the difference between the sum of the lottery operator's income from the lottery organization within the accounting quarter and the sum of the benefit paid by the operator within the same period.

Endowment-funds of sport support, which successfully function in America, are only at the initial stage of formation in the Russian Federation. The main problem during such kind of fund creation is a considerable volume of the initial investments. In the USA, Germany, Great Britain, China, as it was mentioned above, the mechanism of sport tax stimulation was used, as the main source of state support. For sport organizations significant tax benefits for income, property and land are given. In the Russian Federation, according to tax legislation, there exist the range of tax stimuli, which can be 


\section{References}

used by sports organizations and tax benefits for sponsors. Added value tax is not taken of the income from sports events, the definite personal income of athletes. However, it is not enough, tax stimulation in sports sphere has low effectiveness, conditioned by minimal amount of benefits, which are not systematized. Having analyzed the experience of the USA, Germany, England and some other countries, we come to the conclusion about high positive results of sports sphere tax stimulation.

During the scientific research the following results were received:

- the sources of physical culture and sport financing in foreign countries were revealed and characterized. The possibility of their adaptation for the application in Russia was considered;

- the expediency of tax stimulation mechanism broadening in the sphere of physical culture and sport in the Russian Federation was revealed for sports sphere development and also the conditions creation, which would provide people the possibility to go in for physical culture systematically.

Thus, we can say that the effective mechanism of tax stimulation in Russia will provide sports sphere development and the conditions creation. It provide people with the opportunity to go in for physical culture systematically. In the opinion of the authors, it is necessary to change tax legislation in the part of zero tax rate introduction according to tax on income of organizations in the part of sports activity income taxing. At the same time, it is possible to introduce cost limit of benefit use. The alternative can be decreased tax rate of income in a part of a tax, taken into regional budgets. It is important to solve the problem of high tax load on the objects of sports infrastructure. They should be free of tax on property and land, which corresponds with the international practice. Tax deduction introduction on individuals' income in paying for sports sections would provide interest increase of population in sport and physical culture. Such kind of tax instruments will help to stimulate physical culture and sport development in the country.

\section{CONCLUSION}

The mechanism of physical culture and sport financing in Russia is almost completely provided by state resources. In spite of the fact that most foreign sources of sport financing are used in the Russian Federation, the part of direct state financing in Russia is considerably higher. Thus, it is necessary to reconsider the mechanism of physical culture and sport financing in the part of tax stimulation instrument broadening, as this kind of support is successfully used in Russia in the spheres of agriculture, education and others.
[1] Yan Wang, Yue Wang, Ming-Xia "Licharacteristics of sports industry profitability: Evidence from China's province level data” Physica A: Statistical Mechanics and its Applications, Volume 525, 1 July 2019, Pages 946-955

[2] Luke Lunhua Mao, James J. Zhang, Daniel P. "Connaughton Sports gambling as consumption: Evidence from demand for sports lottery" Sport Management Review, Volume 18, Issue 3, August 2015, Pages 436-447

[3] Wolfgang Breuer, Guido Hauten, Claudia Kreuz "Financial instruments with sports betting components: Marketing gimmick or a domain for behavioral finance?” Journal of Banking \& Finance, Volume 33, Issue 12, December 2009, Pages 2241-2252

[4] Bob Stewart "Sport Funding and Finance Sport Management” 2007

[5] Eric C. Schwarz Stacey A.Hall Simon Shibli "Sport Facility Operations Management” 2010, Pages 31-49

[6] Michael Hutchinson, Brennan K. Berg, Timothy B. Kellison "Political activity in escalation of commitment: Sport facility funding and government decision making in the United States” Sport Management Review, Volume 21, Issue 3, June 2018, Pages 263-278

[7] Brad R. Humphreys, Joel Maxcy "The Role of Sport Economics in the Sport Management Curriculum” Sport Management Review, Volume 10, Issue 2, September 2007, Pages 177-189

[8] Arianne C. Reis, Marcelo Carvalho Vieira, Fabiana Rodrigues de SousaMast "Sport for Development" in developing countries: The case of the Vilas Olímpicas do Rio de Janeiro" Sport Management Review, Volume 19, Issue 2, April 2016, Pages 107-119

[9] Kurochkin V.V. "Physical culture and sport financing in Russia" Interaktivnaya nauka. 2016; 10: 137-140.

[10] Sabinina A.L., Kuznetsova A.A. "Physical culture and sport budgetary establishments financing” Izvestiya Tulskogo gosudarstvennogo universiteta. Economicheskie i yuridicheskie nauki. 2018; 4-1: 62-68.

[11] Expert Group on Sustainable Financing of Sport "Strengthening financial solidarity mechanisms within sport" https://ec.europa.eu/assets/eac/sport/library/documents/xg-fin-201211deliverable.pdf

[12] http://www.uksport.gov.uk/about-us/uk-sport-structure

[13] https://www.sportengland.org/funding/

[14] Svenja Feiler, Pamela Wicker \& Christoph Breuer: "Public subsidies forsports clubs in Germany: funding regulations vs. empirical evidence", European Sport Management Quarterly, DOI: 10.1080/16184742.2018.1541915

[15] Haring, M. "Sportförderung in Deutschland. Eine vergleichende Analyse der Bundesländer Sport funding in Germany. A comparative analysis of the states.” Wiesbaden: VS Verlag für Sozialwissenschaften.

[16] BMI. (2016). Federal sport policy. Retrieved 04.12.2016 from http://www.bmi.bund.de/EN/Topics/Sport/Federal-Sport-Policy/federalsport-policy node.html

[17] Ibsen, B., Østerlund, K., \& Laub, T. (2015). Sport clubs in Denmark. In C. Breuer, R. Hoekman, S. Nagel, \& H. Van der Werff (Eds.), Sport clubs in Europe. A cross-national comparative perspective (pp. 85-109). Cham: Springer.

[18] PwC Sports Outlook - At the gate and beyond - Outlook for the sports market in North America through 2022 https://www.pwc.com/us/en/industry/entertainment-media/assets/2018sports-outlook.pdf

[19] Aleksandr S. Kuznetsov. Russian Professor's meeting. Russian Journal of Physical Education and Sport. Pp. 2019, 14(1), 17-22. DOI: 10.14526/2070-4798-2019-14-1-18-24 